\title{
Territorial nature protection system of Siberia and Mongolia
}

\author{
Tatyana Kalikhman ${ }^{1, *}$, and Sandag Enkh-Amgalan ${ }^{2}$, \\ ${ }^{1}$ Sochava Institute of Geography of Siberian Branch, Russian Academy of Sciences, 664033 Irkutsk, Russia \\ ${ }^{2}$ Institute of Geography and Geoecology, Mongolian Academy of Sciences, 15170 Ulaanbaatar, Mongolia
}

\begin{abstract}
The large territory, including Mongolia and Russian Siberia, discussed in the article, has similarities in physical, geographical, and socio-demographic parameters, as well as the attitude to them as "resource colonies". But these Siberian and Mongolian components differ significantly politically, which affects their institutional and managerial characteristics, which in turn affects the process of forming the structure of territorial nature protection. The article analyses the existing systems of protected areas in Siberia and Mongolia, their structure, and legislative bases. In this study, Siberia is considered within the boundaries of the natural geographic territory between the Urals and the Far East and includes 14 regions of Russia. Of these, the Siberian Federal District includes the Altai Republic, Altai Krai, Irkutsk Oblast, Kemerovo Oblast, Krasnoyarsk Krai, Novosibirsk Oblast, Omsk Oblast, Tomsk Oblast, Tuva Republic, Khakassia Republic. The Far Eastern Federal District includes the Buryatia Republic, the Trans-Baikal Krai, Sakha (Yakutia) Republic; the Tyumen Oblast is located in the Ural Federal District.
\end{abstract}

\section{Introduction}

Territorial nature protection or "activities for the preservation, maintenance and restoration of the natural environment in specially designated areas with significant restrictions on the use of natural resources" is usually associated with the operation of specially protected natural areas (PAs). The study covers a geographically unified and significant area of the Asian continent, including the Russian macro region of Siberia and the country of Mongolia. Siberia and Mongolia are similar in their continental location, climate, landscapes, mineral deposits and methods of their development, low density and population, mainly concentrated in cities.

The purpose of the study is to analyze the activities of protected areas in Siberia and Mongolia by comparing the institutional, legislative and structural framework.

\section{Institutional framework}

For a long time, the Soviet Union and the Mongolian People's Republic existed in a single political channel. This led to the fact that at the initial post-perestroika stage of formation of modern legislation regarding the use and protection of lands and the activities of PAs, in many respects, were similar and were adopted almost simultaneously in the 1990s. Over the past two decades, the development paths of countries began to diverge noticeably. This was reflected in the content of the current legislative acts and determined the emergence of a number of distinct features in the analyzed PAs systems due to the changes introduced.
The main acts influencing the PAs functioning are laws on land, on protected areas, on traditional land use.

\subsection{Land laws framework}

In Russia, the "Land Code" is in force (No. 136-Ф3, 25.10.2001), in Mongolia - the "Law on Land" (Монгол улсын хууль "Газрын тухай", 07.06.2002). The Russian Code is much more voluminous and more difficult to apply, since it was regularly amended. The land law of Mongolia is noticeably shorter, stricter in structure, and the changes introduced only concern taxation, the inseparability of land plots and buildings located on them.

In accordance with the law of Mongolia, the "Unified Land Fund" includes several types of land, including "land of special purpose", which includes the lands of PAs. To create a protected area, by its decision, "Great Khural ... can seize and release land for special needs of the state". The central administrative department for land issues has the authority to submit to the Government a proposal for the acquisition or transfer of a land plot for the creation of PAs. If during the creation of a new PA it turns out that the land does not belong to the state, then "aimags, the capital of the country, somons and districts can acquire land for local special needs" in the field of nature protection, with compensation paid to the owner. The law allows foreign organizations and companies to temporarily use the lands of Mongolia for environmental purposes. For example, the Mongolian Environmental Protection Association (a non-governmental public organization), funded by foreign funds, carried out the initial phase of restoration of a limited population of the extinct Przewalski horse in the late 1960s. Subsequently,

Corresponding author: kalikhman@ irigs.irk.ru 
in 1993, a wildlife refuge was created on this site, and later, since 2003, the Hustai Nuruu National Park, managed by the Hustai National Park Trust nongovernmental organization [1]. In Russia, such experiments were possible only in the 1990s, for example, in Yakutia, the Charuoda (WWF-Sakha) resource reserve (organized by 1997).

The Russian code declares "the priority of land protection ... over land use", but in practice the priority is often not respected. For example, when designing a new PA, first of all, the presence of explored mineral deposits is analyzed, the presence of which often slows down or completely excludes environmental protection tasks. In addition, the priority was established for the conservation of PAs, and changing the designated purpose of protected areas for other purposes is limited or prohibited, which is also often not observed in practice. The most striking example was the introduction of a special article (No. 379-FZ, 12.27.2009) into the federal law on protected areas (No. 33-FZ, 03.14.1995), when the lands for the 2014 Winter Olympics in Sochi were removed from the "Sochi national park". Siberia has its own clause on violation of the general spirit of the law on protected areas to exclude from the borders of PAs lands necessary for expanding the infrastructure of the Baikal-Amur and Trans-Siberian railways (No. 254FZ, 31.06.2020).

In the Russian Land Code, in the general list of land categories, among others, there are "lands of protected areas", and provides for "reservation of lands" and "compulsory alienation of lands" for the creation of planned protected areas. In reality, land is not reserved for PAs, but the reservation process is used, for example, during the construction of various structures. In addition, the lands within the boundaries of some categories of Russian PAs (wildlife refuges, natural parks, etc.) do not belong to "PA lands". They are mainly represented by "forest lands" and less often "agricultural lands", which often leads to obvious legal contradictions.

\subsection{Law on territories of traditional land use}

In Mongolia, all livestock-raising activities of the local population are recognized as traditional regardless of nationality. In contrast, Russia has adopted a special law on the territories of traditional land use (TTLU) by indigenous small-numbered peoples (No. 49-FZ, 05.07.2001). The environmental objectives of the law are to preserve biological diversity on the TTLU and to limit the use of natural resources. TTLU are recognized as "specially protected areas" of federal, regional or local significance, but without using the word "natural". Here, economic activity is allowed that does not violate the legal regime of the TTLU.

\subsection{Law on nature protected areas}

The first comparative review of the updated legal environmental framework of Russia and Mongolia was carried out in 2000 [2].
The laws on protected areas in both countries are the main ones that determine the territorial nature protection structure (No. 33-FZ, 14.03.1995; Монгол улсын хууль "Тусгай хамгаалалттай газар нутгийн тухай", 15.11.1994). In Russia / Mongolia, a similar classification has been adopted for national PAs, but regional or local PAs in Russia have their own classification, while in Mongolia they do not. There is one category for each level. Thus, national PAs include, respectively, reserves (zapovednik) / strictly protected areas; national parks; wildlife refuges of federal significance (zakaznik) / nature reserves; natural monuments of federal significance / monuments; and regional PAs are represented by natural parks, wildlife refuges and natural monuments of regional significance, etc. / "PA of aimag". Local PAs include the categories defined by regional laws on PAs / "PAs of somon".

In Russia, buffer zones around PAs are provided only for zapovedniks, national parks, natural parks and natural monuments, few of them have been created due to difficulties in coordination with local administrations. Mongolia adopted a special law on buffer zones of PAs (Монгол улсын хууль "Тусгай хамгаалалттай газар нутгийн орчны бүсийн тухай", 23.10.1997). They can be created around any PAs, and for the joint management of representatives of all land users, a special council of the buffer zone and a fund for its financing are created to take into account all interested parties.

Functional zoning in Russia is assumed only for national and natural parks, and in Mongolia - for strictly protected areas and national parks. Thus, the Mongolian strictly protected areas are more like international biosphere reserves with the differentiation of the environmental regime into zones: 1. intact (unaltered); 2. especially protected (biotechnical activity is possible, elimination of damage from natural disasters). 3. Restricted access where sanitary felling is allowed, construction of campgrounds for temporary stay, collection of certain medicinal and food plants, berries and nuts by local residents, visiting holy places). The most striking example of violation of the environmental regime of a strictly protected area in Mongolia is the "Bogd-khan uul" Nature Reserve. The proximity to the capital of Mongolia has led to significant changes in the natural environment of this protected area: entire city blocks, golf courses, ski slopes have appeared, the number of tourist and recreation centers has significantly increased. Here the natural conditions have changed [3], the area and quality of forests have decreased [4].

For Russian "biosphere reserves", a special biosphere polygon may be allocated "for the purpose of conducting scientific research, state ecological monitoring (state environmental monitoring), as well as testing and introducing rational nature management methods that do not destroy the environment".

In Russia, settlements may be located within the PAs boundaries, which causes difficulties both in the management of a protected natural area and problems with the development of villages. This situation is observed, for example, in the Pribaikalsky National Park (Irkutsk Oblast), but it is most characteristic in the 
Tunkinsky National Park (Republic of Buryatia) [5]. In Mongolia, settlements are not included in the PAs.

Visits to Russian PAs by individuals not living within their borders can be either free or paid, and the amount of payment is determined by the Ministry of Natural Resources and Environment of the Russian Federation. In Mongolia, there is a fee to visit any national protected area.

Both laws declare the priority of international law over national law. Mongolia strictly adheres to the established priority, while Russia quite recently decided to neglect it by adopting a law on the priority of the Constitution of the Russian Federation over decisions of international organizations and courts. In the Law on PAs of Mongolia, a special article is devoted to transboundary and border PAs, as well as the involvement of border guards in their protection. There are functioning and planned transboundary PAs between Siberia and Mongolia [6], but they are not mentioned conditions for their preservation, participation in the protection of the border service and other issues of functioning are not stipulated in relation to them in the Russian legislation.

In the Mongolian Law on Protected Areas, in addition to budgetary funds and funds received from visitors, which increase from year to year [7], financing of protected areas can involve any legal avenues of economic support, including international funds and foreign private donations. In Russia, recently, foreign financing of protected areas has been completely stopped (No. 481-FZ, 12.30.2020).

The Russian law on PAs environmental legislation does not discuss the functioning of protected natural areas of international importance in accordance with ratified international conventions (world natural heritage sites, biosphere reserves, transboundary PAs, key ornithological, botanical, soil areas). A partial exception is the decree of the Government of the Russian Federation on wetlands in accordance with the Ramsar Convention, which simply lists them without discussing a special environmental regime (No. 1050, 13.09.1994). The regime of the above-mentioned Russian "biosphere zapovedniks" has no general rules. These decisions were transferred to the directorates of each such PAs and are reflected only in their regulations.

\section{Structure of the PAs system}

\subsection{Cartographic database}

A general idea of the existing PAs system, their structure and location in each of the countries under consideration is given by cartographic materials, as well as special atlases. For the first time, PAs of Siberia and Mongolia were uniformly presented in the atlas of the Lake Baikal basin [8], for which landscape maps of each PA were compiled. The "one-aspect" method of thematic mapping [6] developed during the creation of the atlas formed the basis for the following two atlases of protected areas: Siberian and Far Eastern federal districts (years of publication, respectively, 2012, 2018) [11-12]. The last district now includes "displaced" purely Siberian territories of the Republic of Sakha (Yakutia), the Republic of Buryatia and the Trans-Baikal Territory). Cartographic information on PAs of Mongolia is available in the latest edition of the Atlas of Mongolia [11-12], and updated as of 2021 - on the website of the Ministry of Environment and Tourism of Mongolia.

The formed database on the modern structure of PAs systems contains statistical and cartographic information about each of the protected areas in Siberia and Mongolia: location, category, creation year, area, management features (for example, special international status) and territorial differentiation (functional zoning, the presence of buffer zones, number of clusters). Cartographic analysis of information makes it possible to assess the distribution of PAs by natural zones and administrative units of the Siberia as a part of Russian and Mongolia. The established systems of these countries PAs differ significantly (Fig. 1).

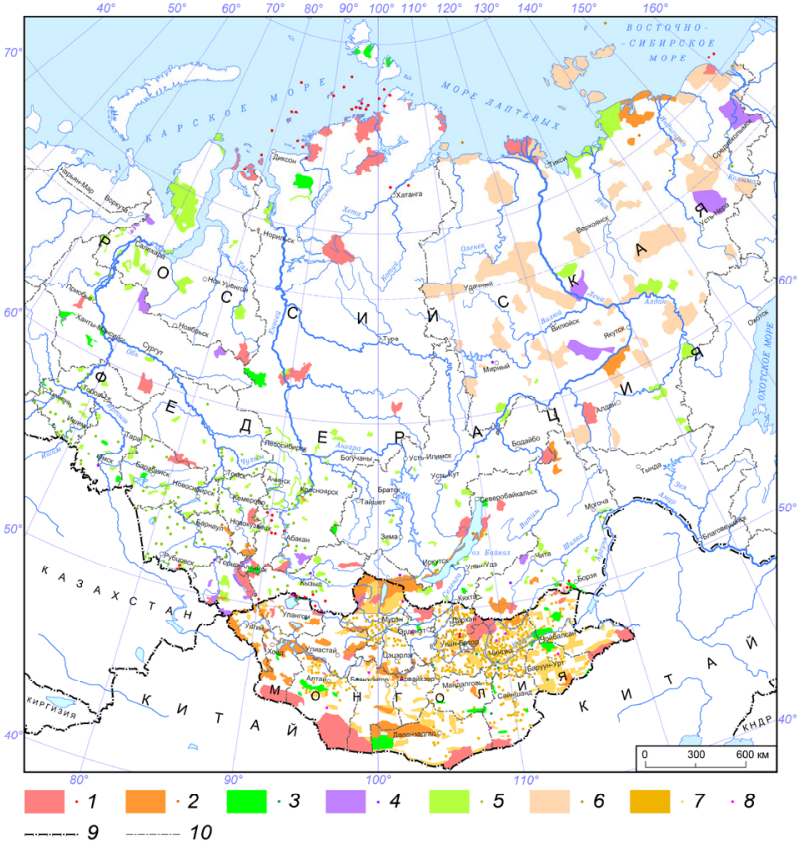

Fig. 1. The PAs spatial location in Siberia and Mongolia.

Categories of PAs: 1 - nature reserve, 2 - national park,

3 - wildlife refuge federal significance, 4 - natural park, 5 - wildlife refuge regional significance, 6 - resource reserve,

7 - aimag protected area, 8 - monument of Mongolia;

Boundaries: 9 - state, 10 - between regions of Russia (krai, oblast, republic) or aimags of Mongolia

Most of the Siberian PAs are concentrated in its southern limits, along transport routes and in areas of settlement. An exception in terms of the regular location of PAs can be called the situation in Yakutia and partly in the Tyumen oblast (with the Yamalo-Nenets and Khanty-Mansi autonomous okrugs). The tendency of irregulars is especially pronounced in relation to wildlife refuges of regional significance. The location of PAs across the physical and geographical regions of Siberia is also irregularly. Mountain and South Siberian types of landscapes are widely represented within the boundaries of the Siberian PAs, while the arctic, subarctic 
landscapes, north and middle taiga forests are insufficiently covered and are noted only in several large protected areas of federal significance in the northern part of Siberia.

In Mongolia, the location of PAs is more regularly, both in the administrative division of the country and in natural zones and altitudinal belts, starting with alpine landscapes and mountain forests and ending with steppes and deserts.

The "monuments" category in Mongolia differ noticeably from the "natural monuments" in Russia. Mongolian monuments are few in number, have a national status, and their area is usually comparable to the area of wildlife refuges.

\subsection{Statistical analysis results}

The number of PAs in Siberia is 2.5 times less than that in Mongolia (Table 1). The share of the corresponding total area of PAs from the areas of Siberia and Mongolia is $11.55 \%$ and $26.75 \%$, respectively.

Table 1. Summary data on the structure of nature protected areas systems in Siberia and Mongolia as of 01.01.2021.

\begin{tabular}{|c|c|c|c|}
\hline $\begin{array}{c}\text { Nature } \\
\text { protected } \\
\text { areas } \\
\text { categories } \\
\text { (Russia / } \\
\text { Mongolia) }\end{array}$ & $\begin{array}{c}\text { Number } \\
\text { PAs }\end{array}$ & $\begin{array}{c}\text { Area, } \\
\text { thousand } \\
\text { hectares }\end{array}$ & $\begin{array}{c}\text { Area's share } \\
\text { of Siberia / } \\
\text { Mongolia, \% }\end{array}$ \\
\hline $\begin{array}{c}\text { Nature } \\
\text { reserve / } \\
\begin{array}{c}\text { Strictly } \\
\text { protected area }\end{array}\end{array}$ & $28 / 15$ & $\begin{array}{c}20138 / \\
13342\end{array}$ & $2.09 / 8.53$ \\
\hline $\begin{array}{c}\text { National } \\
\text { park/ national } \\
\text { park }\end{array}$ & $13 / 34$ & $7050 /$ & $0.73 / 8.12$ \\
\hline $\begin{array}{c}\text { Wildlife } \\
\text { refuge of } \\
\text { federal } \\
\text { significance / } \\
\text { Nature } \\
\text { reserve }\end{array}$ & $19 / 45$ & $3592 / 5253$ & $0.37 / 3.36$ \\
\hline $\begin{array}{c}\text { Natural park / } \\
-\end{array}$ & $22 /-$ & $9680 /-$ & $1.00 /-$ \\
\hline $\begin{array}{c}\text { Wildlife } \\
\text { refuge of } \\
\text { regional } \\
\text { significance / } \\
-\end{array}$ & $267 /-$ & $24270 /-$ & $2.51 /-$ \\
\hline $\begin{array}{c}\text { Resources } \\
\text { reserve / }\end{array}$ & $63 /-$ & $46812 /-$ & $4.85 /-$ \\
\hline $\begin{array}{c}\text { Monument } \\
\text { - }\end{array}$ & $-/ 13$ & $-/ 104$ & $-/ 0.07$ \\
\hline $\begin{array}{c}\text { - / Aimag } \\
\text { protected area }\end{array}$ & $-/ 952$ & $-/ 10434$ & $-/ 6.67$ \\
\hline $\begin{array}{c}\text { Total } \\
\text { Moral }\end{array}$ & $412 / 1059$ & $111542 /$ & $11.55 / 26.75$ \\
\hline
\end{tabular}

The area of these Mongolian PAs is 2.5 times larger than the Siberian ones. It should also be noted that a significant part of the aimag's PAs officially presented in the inventory of the Ministry of Environment and Tourism of Mongolia is still given without specifying their area. For example, out of 21 regional PAs of Bayankhongor aimag, the area is indicated only for two, out of 48 Umnugov aimag - for 26, out of 47 Sukhbaatar aimag - for 13, from 155 Tuv aimag - only for 10 , out of 128 Khuvsgul aimag - for 23, and in aimags Bulgan and Khovd are not for one. It is clear that the real area of aimag PAs is significantly higher. Even in such "truncated" form, the area of aimag PAs is comparable to the area of strictly protected areas or national parks. Wildlife refuges and monuments are less represented.

In general, there are 412 PAs of the main categories in Siberia. Of these, 60 are PAs of federal significance and 352 are PAs of regional significance. It can be seen that the largest number of PAs, including PAs of regional significance, are located in Yakutia, Krasnoyarsk Krai and Tyumen Oblast, but these are also the largest regions of Russia. The PAs of federal significance maximum number is presented in the Krasnoyarsk region (11) and the Tyumen region (9), and in the north of the first there are three of the country's largest nature reserves (zapovedniks). The Republic of Altai (PAs make up part 1/4 of the area of this Russian Federation region) and Yakutia (more than 1/5), in the worst situation is in Irkutsk Oblast and Tomsk Oblast (less than 4\%) are covered by the environmental regime to the minimum.

Nature reserves (zapovedniks) in Siberia occupy a significant part of the territory under consideration $(2.09 \%)$ and almost $1 / 6$ of the area of all Siberian PAs. National and natural parks are still the least represented. Despite the small area of each federal and regional wildlife refuges (zakazniks), their total area significantly exceeds the total area of strictly reserves. But the most significant in terms of area both within the region and for the whole of Siberia are 62 "resource reserves" of Yakutia - almost $42 \%$ of the area of all PAs, which is 2.5 times the area of all zapovedniks, and occupies almost $1 / 20$ of the area of all Siberia. Resource reserves are a category of PAs functioning only in Yakutia with a not very strict environmental regime. They allow the conduct of traditional types of land use on a part of their territory, while preventing the emergence of intensive types of nature use and industrial facilities.

Siberian PAs almost never cross the borders of the Russian regions (the exception is the Vasyugansky nature reserve between Novosibirsk and Tomsk regions). In Mongolia, transboundary inter-aimag PAs are very widely represented (for example, out of 15 strictly protected areas, 7 are interregional, out of 34 national parks - 15).

\section{Conclusion}

The territorial nature protection of Siberia and Mongolia is united by transboundary protected natural territories (TPNT) of the interstate level. In particular, these are the functioning TPNT Altai, Ubsunurskaya Kotlovina, Dauria. At the end of the organization, the process is in 
the TPNT "Sources of the Amur river". The following TPNT are planned between Russia and Mongolia: Sailyugem, Delger-Muren, Sayan Cross, From Khuvsgul to Baikal, Selenga, Khentey-Chikoy Upland (6). For each TPNT special interstate agreements are concluded.

As for the rest, the development and structure of the PAs systems are noticeably different.

In Russia, all the federal end regional ministries responsible for the functioning of PAs also carry out the tasks of expanding the use of natural resources. These tasks are essentially opposite to each other. The goals set for the development of the PA system in Russia are constantly not being met, moreover, they are often sabotaged, and the nature protection regime of PAs is violated. Until recently, the only exception was the Ministry of Nature Protection of Yakutia. The situation changed in 2020, when it became known as the Ministry of Ecology, Land Use and Forestry Use of the Republic of Sakha (Yakutia).

Mongolia gives the Ministry of Environment and Tourism full responsibility for nature conservation and the PAs management. Achievement of $30 \%$ of the country's area has been declared as the goal of development of the PAs system [7], and it has almost been achieved. The share of PAs from the area of Mongolia is already almost $27 \%$. Everything related to the development and extraction of natural resources remains within the framework of other departments, and the intersections and contradictions that arise are resolved at a high government level. This independence allows one on a regular basis for two decades to create new protected areas, have plans and state programs for the development of the network of PAs, which are consistently implemented. As a result, we can note the constant implementation of work to expand the existing and justify the organization of new protected areas. For example, in the Mongolian Altai area, it is planned to organize 42 PAs, in the Khangai Ridge territory and Lake Khubsugul area - 62 PAs, in the South Gobi region - 64 PAs [13-15].

The area of Siberia is about five times larger than the area of Mongolia. At the same time, the total area of protected areas of these countries is comparable. The main differences between the PA systems of Siberia and Mongolia lie in the content of the legislation, the strictness of its implementation, as well as in the existing management structure.

The article was prepared as part of the project of the Russian Foundation for Basic Research (RFBR) and the Ministry of Environment and Tourism of Mongolia N 20-55-44023.

\section{References}

1. K. Wurts, Mongolian National Parks: Competing Interests and Institutional Viability in a Still Emerging Protected Areas System, 44, Ulaanbaatar (2013)

2. T.P. Savenkova, Environmental Legislation of Mongolia and Russia: Comparative Review, Steppe Bulletin 6, 54-58 (2000)
3. N. Erdenechimeg, I.A. Belozertseva, D. Enkhtaivan, The current situation in the organization and management of specially protected natural areas of Mongolia (on example of the mountain rezerve Bogdhaan), Success of modern natural science 1, 121-126 (2017) URL: http://naturalsciences.ru/ru/article/view?id=36353 (date accessed: 2021.03.21)

4. D. Tsendsuren, The state of larch plantation (Larix sibirica Ledeb.) in green zone of Ulaanbaatar and the prospects for their recreational use: Author's abstract dis., agricultural sciences, 24, Saint Petersburg (2009)

5. T.P Kalikhman, Tunkinsky National Park: People or Nature, Zapovednoe Delo 12, 92-111 (2007)

6. A.V. Bardash, T.P. Kalikhman, Cartographic Foundation of Transboundary territorial Nature Protection in Siberia and the Far East, Geodesy and Cartography 81 (4), 51-64 (2020)

7. B. Oyungerel, State and prospects of nature protection in Mongolia, Bulletin of the Botanical Garden-Institute of the Far Eastern Branch of the Russian Academy of Sciences 1, 88-93 (2007)

8. T.P. Savenkova, Protected natural areas of the lake Baikal basin. Atlas, 96, Irkutsk (2002)

9. T.P. Kalikhman, V.N. Bogdanov, L.Yu. Ogorodnikova, Specially protected natural areas of the Siberian Federal District. Atlas, 384, Irkutsk (2012)

10. T.P. Kalikhman, A.V. Bardash, V.N. Bogdanov, L.Yu. Ogorodnikova, E.M. Klimina, V.N. Bocharnikov, Specially protected natural areas of the Far Eastern Federal District. Atlas, 588, Irkutsk (2018)

11. National Atlas of Mongolia, 248, Ulaanbaatar (2009)

12. B. Oyungerel, The system of specially protected natural areas of Mongolia and prospects for its development, Arid ecosystems 16 (3), 57-66 (2010)

13. Environmentally Planning Development in the Ecological Region South Gobi region of Mongolia. Environmental description of areas that need protection and are ecologically important, 431, Ulaanbaatar (2014)

14. Environmentally Planning Development in the Ecological Region of the Mongol Altai Mountains, Great Lakes Depression and Lake Valley: Definition of ecologically important areas that need to be protected, 353, Ulaanbaatar (2017)

15. Environmentally Planning Development in the Ecological Region of the Khangai and Huvsgul ecological regions of Mongolia. Environmental description of areas that need protection and are ecologically important, 590, Ulaanbaatar (2017) 